\title{
The Philosophy-Psychology Linkage
}

\author{
Amos Avny \\ Omnidev International, Yehud, Israel \\ Email:amosav@smile.net.il
}

How to cite this paper: Avny, A. (2018). The Philosophy-Psychology Linkage. Open Journal of Philosophy, 8, 216-224. https://doi.org/10.4236/ojpp.2018.83016

Received: March 5, 2018

Accepted: May 8, 2018

Published: May 11, 2018

Copyright (C 2018 by author and Scientific Research Publishing Inc. This work is licensed under the Creative Commons Attribution International License (CC BY 4.0).

http://creativecommons.org/licenses/by/4.0/

\begin{abstract}
The Essay explores two questions about the subject: a. whether exist any linkage between Philosophy and Psychology, and b. what is the nature of this linkage? Actually, the Author answers that such a linkage already exists. In fact, these two disciplines are like two sides of the same coin, they are complementary rather than competitive. For clarifying this argument the Author discusses 3 example cases, examining the whole individual-organization complex. The Essay describes Adam and Eve's nature and curiosity, qualities that empowered them in their search for knowledge. This behavior also made them the fore-parents of all explorers, pioneers and researchers who followed them. Further, the Author indicates how wrong use of ideological declarations hurts individuals and subdues them. Finally, the Author advocates the introducing of the "Normal Distribution Method" and the "Bell type Curve" as main tools in teaching and studying Social Sciences.
\end{abstract}

\section{Keywords}

Curiosity, Intellectual Bravery, Self-Esteem, Liberty, Equality and Fraternity, "Normal Distribution Theory" and "Bell Type Curve

\section{Introduction}

Some will wonder whether there exist connections between the two major disciplines, Philosophy and Psychology.

Philosophy deals, teaches and studies all the transcendental, cosmopolitans, spiritual and cultural aspects of human society. It also affects many of the Social Sciences, like, Politic, Economics, Public Administration, Management and more.

Psychology examines and studies the individuals themselves. It tries to know and understand the individual's inner-self, the internal complex of vectors that steer and direct the behavior of human and some unhuman creatures.

The $20^{\text {th }}$ Century scientific research modes had promoted the separation and 
specialization of most of the scientific fields and by this way deepening the knowledge and widening the professional understanding. As a result, the expertise of many specialists and well-known experts grew and deepened. However, the connections between different disciplines and their inter-relationships and mutual influences, did not get enough attention.

I have no doubts that if some the $20^{\text {th }}$ Century's Political Leaders had forced to accept a proper psychological treatment the life of tenth million were save.

The $21^{\text {st }}$ Century, led by the chaos perspective and attuned to other holistic approaches, promotes a more holistic attitude in many fields of science. Such a comprehensive approach is even more helpful in the areas that study human's life and behavior. It is, therefore, this point of view leads me also and is the port from which I depart when examining the following three sample cases.

\section{Examination of Three Sample Cases}

\subsection{The Biblical Story on Adam and Eve in the Garden of Eden}

Although this is a Biblical story still it is relevant for our discussion. It well demonstrates how a human decision, initiated by the basic elementary sense of curiosity, and empowered by a keen sense of challenging, drove Adam and Eve to taste the forbidden fruit. The story tells us quite frankly that in the Garden of Eden they had all they needed. The Bible tells that all their materialistic needs were fulfilled and all their desires were met. And still they were doubtful, looking for the unknown experience and being exited and inspired by the chance to find something new.

In this respect it is fair to note that Adam and Eve were the predecessors and the ancestors of many great researchers, discoverers and explorers. Similar drives and motives had driven them to question and doubting the prevailing situation. They were initiating and enacting new modes and novel ways for changing life. They try bravely to accomplish and fulfilling basic desires while accomplishing their challenges.

Led by this perspective, we reject the traditional Biblical traditional approach, which perceives this act of Adam and Eve as the Prime Sin of Human beings. Some thousand years ago, Adam and Eve were motivated by psychological drives that act, steer and have an impact even today, on many people. They also were courageous enough to listen to their inner desires and to follow their internal heart and soul commands.

Similarly, we also reject the form and type of the punishment imposed by God on them, as mention in the Bible:

The curse to Eve was:

"I will greatly multiple thy sorrow and thy conception; In sorrow thou shalt bring forth children; and thy desire shall be to thy husband, and he shall rule over you" (Genesis Ch 3,16$)$.

While to Adam The Lord God said: 
"Because thou hast hearkened unto the voice of thy wife, and hast eaten of the tree, in which I commanded thee, saying Thou shalt not eat of it, curse is the ground for thy sake; in sorrow shalt thou eat of it all the days of thy life" (Genesis, 3, 17).

The story of Adam and Eve in the Garden of Eden well demonstrates the linkage between human personality (being studied by Psychology) and the outer environment, both natural and spiritual (being addressed by Philosophy). The Biblical traditional school sees the involved couple as one who have weak personality and tend not to follow instructions, thus they are "Disobedient." We, on the other side, oppose this approach and offer a different perspective.

For me Adam and Eve represent people who are curious, who look for widening their education and are ready to take extreme measures for enabling them acquiring more knowledge. They are the forefathers of Galileo, Copernicus, Newton and Einstein. They also should be commended since they were accountable, were ready to be responsible for their deeds and be punished if necessary.

Unfortunately, we know many individuals, of all walks of life, who are willing and sometime even decisive to offer a philosophy, suggesting a utopia or calling for a change, while they, personally, are running away from any consequence.

About the curse or the punishment of this story. Lord God cursed Adam and Eve by "multiplying their sorrow" while having babies or tiling the land. First, I reject the attempt to link birth with sorrow. Every female, woman or a mother, all over the globe, will agree and claim that having babies is among the most exciting experiences every woman seeks. The real pain appears usually when having babies becomes impossible. Nowadays, Billions of Dollars, thousands of Doctors' working hours and many and many women spend enormous efforts just removing this curse of Eve.

The curse to Adam, "in the sweat of thy face shalt thou eat bread" (Genesis, 3, 19), demonstrates also a serious misunderstanding. Nothing on earth, physically, mentally or spiritually could be achieved without investing energy, intuition and sweat. Creation of a new entity or participating in constructing a novel system demands continual efforts and permanent creativity. Without sweat, actual or metaphorical, nothing could be built. Philosophers and ideologists are important however, doers and builders are those who give the final touch and form.

The above story, about Adam and Eve, is an indispensable part of the Holy Bible. Almost for ages and among the biblical religions, these divine curses have been accepted as the ultimate message of the Lord God. Naturally, obedience and compliance with the System's rules and regulations, was and still is the prime demand of every regime, secular or religious. However, does such a demand for obedience meet the real interest of the people? does it comply with the interest of those who sought progress? I doubt. May I suggest to see their behavior at the Garden of Eden, as the early symptoms and the very first indicators of what later will be recognized as the Jewish or Israeli's "Hutzpah". Maybe the 
primary seeds and the initial factors that made "Israel-a Start-up Nation" were saw and incubated within Adam and Eve disobedience and curiosity, when they were in the Biblical Garden of Eden.

The above case well demonstrates the linkage and contradictions between the individuals' desires and wishes Vis a Vis the ideology of the regime. Adam and Eve preferred to disobey and opposing the dominant philosophy because it did not fit their ideas. Furthermore, the participants were fair enough and willing to bear the punishment that was given to them.

\section{2. "Liberty, Equality and Fraternity" and Beyond}

The above phrase represents a different aspect of the connection between Philosophy and Psychology. This case describes how a public declaration, on desired Social Order and Just, had been circumvented and abused by powerful rulers. This case demonstrates how great ideas that had originated by devoted Just seeking people were further used for suppressing and dominating over them. In short, history told us that The French Revolution terminated with Napoleon's imperialism, the Weimar Republic had resulted with Hitler's evil regime, while the Russian Communist Revolution had produced the Stalin's awful Dictatorship. Is it fair? Does it fit the dreams and the hopes of initiators? I do not know. However, it clearly indicates that having a great idea or an inspiring philosophy do not ensure attaining Just results. Eventually, real life experience is what determines people's feelings and behavior.

Liberty, Equality and Fraternity raises three prime social values that symbolized the inspirations, wishes and hopes of the French Revolutionaries, some two hundred years ago. Although the historical authors put the three words together they insisted on an internal order. Liberty, or Freedom comes first, afterward, legal and formal Equality while Fraternity came last, since it is a result of long social education. The original initiator of the slogan well-understood the sequence of the words and tried frequently to emphasize the crucial role of Liberty as the process's jump starter. It was obvious that without political freedomLiberty, there is no chance to attain the other two goals.

However, in spite of all the obstacles, the French declaration had been used as a poster and a banner for a large number of revolutions and reforms in many countries abroad. This declaration tried to referred to internal hidden wishes.

This call met concealed hopes and inspired every developed person in the $18^{\text {th }}$ century.

Unfortunately, history teaches that good intentions and even inspiring hopes cannot promise a satisfactory implementation. During the $19^{\text {th }}$ Century and the first decades of the $20^{\text {th }}$ one, Democracy suffered in most countries in Europe. Many countries were not liberated yet and the popular political regime was a mix of Monarchy and several types of authoritative regimes.

At the $20^{\text {th }}$ Century dictatorial regimes came to power in Europe and this fact enabled them to disregard individuals' rights, disrespect their wishes and neglect their needs. Dictatorships, like Nazi Germany or Communist USSR, which pay 
little attention to their citizen's emotional and psychological needs degrade also the justification for promoting psychology. For decades psychologists in those dictatorial states have no choice, they were forced to work for the Government. These governments did not allow provision of personal psychological services to common people. Dictators use those services, only when it was congruent with their ideology and the Regime's needs. The Regime captains demanded that citizens will behave in accordance with the official guidance. Little room was left for private or individual wishes. Citizens were perceived as figures or chess peons. From this point of view, all citizens were the same, equal in their inability to be original and unable to think creatively. Dictatorial regimes had adopted Equality from the French Declaration, because it met their philosophy. It followed their philosophy that perceived citizens as subordinates and animals who live and die together in a herd.

Furthermore, behind the three values' phrase was concealed a common call; All of them referred to individuals and were aimed to the single individual wishes. They presented goals and objectives that every person, in every liberated country, should ultimately attain. However, a concealed balance and internal order were hidden beyond the three values; Nothing could be achieved before Liberty is attained. Equality refers mostly to legal and formal equalities, while Fraternity depends on long-term meaningful education.

After the Great Revolution, along the $19^{\text {th }}$ Century, the impact of this slogan on social struggles was just like other declarations and wish-full expressions. It was mainly a theoretical declaration of intentions.

At the $20^{\text {th }}$ Century, after the First World War, when Nationalism became an issue, more and more nations in Europe, tried adopting this call. Many got their political independent and a new Era started guiding political behavior. At this time the internal balance between the three values begun failing. In addition, the individualistic aspect of the values lost its weight. Social and political movements discount the personal meaning of the phrase and put all the weigh on the national and social aspect. Three of the major political movements that prevailed in Europe during the 1920's and 1930's, Fascism, Nazism, and Communism were of this type. These three ideologies, in different ways, taught and preached that the state and its interests and commands precede the wishes and the aspirations of the individual. Every single man and woman should enslave their aspirations and hopes to the control and the guidance of the regime. In this way, within few years, "Liberty Equality and Fraternity" discontinued to be a personal goal and a humanistic promise and had become a regime value. This transformation was accompanied by the conception of centralized, authoritarian and dictatorial regimes, which had, firmly and cruelly controlled the life, and the death of its citizens. These dictatorial philosophic and political regimes were responsible for the death and parish of tenths million people.

Unfortunately, this is also a living demonstration of how a well-aiming, humanistic, individual promise, can, due to improper use becomes a leading philosophy of evil-seeking regimes. 
In concluding this section, I would like to emphasize that in the past linkages or connections between Philosophy and Psychology did not come automatically. At present, when such a cooperation is much more necessary, many efforts and much energy should be directed for attaining this goal.

\subsection{The Meaning of "We the People"}

"We the People... in order to form a more perfect union, establish justice, insure domestic tranquility, provide for the common defense, promote the general welfare, and secure the blessing of liberty..."

The first part of this famous preamble, used frequently for many purposesWe the People-arises from the beginning two questions; first who is We, and second, who are the People? In fact, nobody today tries to cope with these issues, since they were authored two hundred years back. At present, after the Civil War, the anti-segregation acts and the struggles for civil rights many tend to claim the popular sentence that "all people are equal." This was not the leading philosophy when the Constitution was written. The Founding Fathers have perceived themselves and their neighbors as-Gentlemen - the legitimate members of the new Union. They have excluded from this group, Women, Blacks and Slaves. The regime they have tried to portray was, therefore, the one that fitted their philosophy. Later we will try to offer a different philosophy, a one that will fit the personality and the inspirations of the present generation.

The American founding fathers, when convened in 1787 for creating the system of the Federal Union were less philosophical and more specific than their French colleagues. They almost did not use worthy words like Liberty and Equality while preferring guiding terms for describing their goals. However, the American founding fathers understood that Liberty precedes every other value and without Freedom no other value could be achieved. Thus, for over two hundred years continued in US the struggle for freedom and attaining civil rights until it ended, symbolically, with the election of the first Afro-American as President of the US.

Now, at the second decade of the $21^{\text {st }}$ Century, after Barak Obama concluded his Presidency, time comes for examining the meaning Equality and the derived terms "Equal Rights" and "Equal Opportunities."

As long as these are political or Ideological declarations, like the French famous slogan, it is acceptable. Even as operational directives they can work. However, the problem lay when it comes to implementation. The philosophical meaning of equality does not fit reality. Human society is not a group one type and one shape of people. An old Jewish say proclaims that: "People's souls and minds vary similar to their faces and appearance". Some writers and ideologists tended to claim that "all people are equal" or "all human-beings are the same". We challenge this declaration and insist on a more Post-modern argument that claims that: "all people are not the same, they don't look the same and they do not think and feel the same." Thus, future communities in liberated and 
Democratic states, will be constructed of dissimilar, vary people. Future societies will contain a variety of citizens. They will be pluralistic, each with his or her specific needs and demands. Due to the fact that we refer to free Democracies, most of them will be quite affluent. It is easy understanding that the classical argument of "an Aggregated Demand" is losing ground. People today, in the West, after meeting their basic needs, tend to buy what they wish, rather than what they need, because they need very little. Consequently, World Trade in general, and World Aggregated Demand, particularly, will grow fast but in unpredictable directions.

Resulting from these developments comes the call to make the "Normal Distribution Method" as the major statistical method for analyzing, describing and referring to human societies and groups. The Normal Distribution Method expressed also by the "Bell type Curve" claims that every human society contains three groups; One minority group of a talented, competent and a very high performing ability, and one minority group of a low performance. The third group is the majority, which contains all the different others. It is understandable that every given discipline or virtue is constructed of a group of people arranged according to its specific Bell-shaped Curve. One person can be affiliated with several quality groups, not only one. His or her contributions are usually evaluated within their specific professional group rather than among the general public.

Although this type of categorizing and assorting living creatures is very popular in natural and environmental studies, ideologists and humanists may reject its introduction into Social Sciences. This may be another living example where Philosophy and Ideology interfere and disturb the course of scientific work.

Introducing a new or a different point of view into the running practices of Social Sciences is not an easy undertaking. Claiming that "All people are not equal" may evoke writers and social activists who, referring to Moralism and Justice, continuously preach the opposite. It is our deep and sincere belief that for conducting fair and honest research, scientists must adopt the "Normal Distribution Theory" when analyzing human societies. The challenge of the $21^{\text {st }}$ century's Social Sciences is quite difficult. They have to provide an authentic picture of the Post-modern Chaotic Social World. The unpredictable fast development of Technology in general, and the exponential outbreak of the communication and Media fields, in particular, makes such a request even harder.

\section{Conclusions}

The lessons learnt from the three discussed examples are obvious and quite helpful:

First, it demonstrates that the crucial importance and the significant impact individuals and individual's determination have on further developments. The said individuals must have high self-esteem, must be doubtful and little disobedient but must also be competent and accountable. These are the 
personal virtues that characterize entrepreneurs, land-explorers, pioneers and researchers. Although, I believe, that these qualities are genetical, a proper psychological support may assist in further developing them. My main message here is that everyone, every woman and man, in liberated democratic society, is entitled to have the opportunities of developing his/her personal abilities and talent, even if the social environment do not promote it.

Secondly. Declarations on High Valued Goals and Moralistic Objectives are quite popular. Autocratic rulers and revolutionary regimes frequently publish them as the Regime Goals. Unfortunately, all types of Government tend to forget the importance of their citizens' personal rights and their limited freedom. Autocratic regimes, tend, and know how to twist general proclamations into directives that fit their needs. Unfortunately, there are enough less-developed people, insecure persons and feeble individuals that follow these regimes. Psychology and education may help developing those citizens, but usually they are limited or somehow rejected.

Thirdly. Resulting from the Equality of the poor and those who have little, people support the erroneous argument that "all people are equal". The $21^{\text {st }}$ Century prosperity and the expansion of Democracy as the most popular regime on earth, enable to present the more appropriate declaration: "Although people are equal in their legal and formal rights and obligations, they still differ in their virtues and competence." This momentous change in many of the leading Social Sciences must also affect their research methods. Human Societies should, from now-on be taught and studied, analyzed and described by using the "Normal Distribution Theory" and the "Bell shaped Curve".

Fourth. A concluding conclusion.

At the second decade of the $21^{\text {st }}$ Century, while the Post-modern approach recruits more and more supporters it is time to examine and rethinking many of the former methodologies in both Philosophy and Psychology. Although the World at large, and Human-beings in general, remain the same, as they were for years. But, activities, relationships, influences and mutual interrelations have changed dramatically. The World is in a move, little today looks as it was in the past, basic philosophical assumptions have to be reexamined. With regard to people the picture looks the same. Liberated affluent democracies, fast technological availability of enormous data resources and communication and Media rapidly growing open new spiritual and virtual worlds for millions. While many have learnt to use these new opportunities, others are still being challenged by these new opportunities. Psychologists and Therapists are requested to enhance and enrich their treatments while generating novel tools for supporting needy people.

The Post-modern working models should be more holistic, attuned to new technologies, referring to the individual's inner-self, personal troubles and their confrontation with the new, chaotic, uncompressible, virtual and sometimes perplexing reality.

The role of the Academy today is drowning new avenues for studying So- 
cial Sciences in the future and makes it congruent with the changing world. Below are detailed some guiding ideas for improving the study of future Social Sciences. Using Normal Distribution Analyzes, promoting Inter-disciplinary study and research, encouraging mind-opening and creative thinking, while supporting team-working and cooperation.

We hope that better and more relevant results will be attained when philosophers will be able to speak with people and psychologists will enjoy describing stars.

\section{References}

The Holy Bible-King James Version. 